\title{
Allometric equations for estimating the above-ground biomass of Castanopsis indica at juvenile stage
}

\begin{abstract}
S. K. Bhandari ${ }^{1}$ and $H$. Neupane ${ }^{2}$
Most of the Castanopsis indica forest of Nepal in the midhill region was degraded in the recent past especially due to policy conflict between government and local users. But after the introduction of community forestry system, these forests have been rejuvenated gradually. Therefore, the proportion of the juvenile plants in forests is very high and the contribution of juvenile plants on total biomass production cannot be overlooked. Therefore this study was carried out to develop juvenile biomass models. We measured diameter at $10 \mathrm{~cm}$ above ground level $(D)$, total height $(H)$, density $(\rho)$ and total biomass $(W)$ of indica juveniles. The models were estimated using "library (minpack.Im)" in R. The estimated models were evaluated by using numerical fit statistics and graphical analyses. The selected model $\hat{W} i=52.28\left(D_{i}^{2} H_{i}\right)^{0.89}$ explained $>95 \%$ juvenile biomass of indica with $\mathrm{RSE}=42.34 \mathrm{~g}, \mathrm{AIC}=406.8$ and average deviation=13.26.
\end{abstract}

Key words: Biomass, Castanopsis indica, juvenile, model, Nepal

C Tastanopsis indica (Roxb.) Miq. (family Fagaceae), commonly known as Indian Chestnut, is a broadleaved evergreen tree species of middle hills of Nepal. It is generally found in association with Schima wallichii in high rainfall area of Annapurna region and eastern Nepal. This species is found between $1200 \mathrm{~m}$ to $2900 \mathrm{~m}$ above the mean sea level (Jackson, 1994). The main stem of this species is commonly used as construction timber, leaves as fodder and raw materials for local plates, branches as fuelwood and fruits as food. Most of the $C$. indica forest of Nepal in the midhill region was degraded in the recent past specially due to policy conflict between government and local users. But after the introduction of community forestry system, these forests have been rejuvenated gradually. Therefore, the proportion of the juvenile plants (defined as a plant $\geq 30 \mathrm{~cm}$ in height and $<10 \mathrm{~cm}$ in stem circumference at $10 \mathrm{~cm}$ above ground surface (Chaturvedi et al., 2012)) is very high. Almost 5\% contribution was recorded from juvenile stage plants in total biomass production (Francis, 2000). Juvenile plants also contribute significantly for the protection of land through minimization of soil erosion. Therefore, juvenile plants play a vital role in maintaining the balance in overall ecosystem of forest and cannot be overlooked in forest biomass and carbon assessment.
The study of size-correlated variations in organic form and process in biological sciences is traditionally called "allometry" (Greek allos,"other" and metron, "measure") (Niklas, 1994). The allometric equations can be used to estimate the above ground biomass and carbon of the particular forest area (Hosoda and Iehara, 2010; Chaturvedi et al., 2012; Subedi and Sharma, 2012). However some other direct methods (Cutting of plants and weighing of their parts to estimate biomass) can also be used to estimate the biomass and carbon in a forest stand (Ketterings et al., 2001; Basuki et al., 2009). Since the area of the forest is large (in most of the cases), the estimation of biomass through destructive felling is not possible and not beneficial also in all cases. Therefore uses of indirect methods such as using allometric equations are considered better option in comparision to direct methods (Hosoda and Iehara, 2010; Chaturvedi et al., 2012; Subedi and Sharma, 2012).

Large sized forest plants have been extensively used in biomass estimation and preparation of allometric equations (Keith et al., 2000; Segura and Kanninen, 2005; Zianis et al., 2005; Muukkonen, 2007). But very few studies can be found in which small sized plants have been used for biomass studies (Wagner and Ter-Mikaelian, 1999; Geudens et al., 2004; Chaturvedi and

\footnotetext{
Department of Social Forestry and Forest Management, Institute of Forestry, Nepal, Email: shesu15@yahoo.com

Department of Forests, Ministry of Forests and Soil Conservation, Kathmandu, Nepal
} 
Raghubanshi, 2013; Chaturvedi et al., 2012; Chapagain et al., 2014). In most of the cases, biomass and carbon are estimated by excluding the juvenile plants and therefore underestimation is also realized. One of the reasons for this is the unavailability allometric equations for juvenile stage plants. Therefore, it is worthwhile to include juvenile plants in biomass studies. Though Tamrakar (2000) has developed biomass table for C. indica and Shrestha (2013) has developed biomass models for large sized $C$. indica, so far, to the authors' knowledge, no biomass studies have been conducted for juveniles of $C$. indica in Nepal. Therefore this study was carried out to develop allometric equations for juveniles of C. indica which is expected to contribute to the carbon trade programs of Nepal in front of the international community.

\section{Materials and methods}

\section{Study site}

This study was carried out in Bhakarjung Community Forest of Dhikurpokhari Village Development Committee (VDC) of Kaski District (Fig. 1) (28 $06^{\circ} \mathrm{N}$ to $28^{\circ} 36^{\prime} \mathrm{N}$ latitude and $83^{\circ} 40^{\prime}$ E to $84^{\circ} 12^{\prime}$ E longitude) Western Nepal. The total forest area in the district is $93,649.85$ ha $(46.43 \%)$ out of which $65,073.61$ ha $(69.49 \%)$ area is covered by Annapurna Conservation Area (ACA) and the remaining 28,575.48 ha (30.51\%) is managed by District Forest Office (DFO), Kaski. The altitudinal range of this district varies from $490 \mathrm{~m}$ to $8091 \mathrm{~m}$ from the sea level. Its average maximum temperature is $33^{\circ} \mathrm{C}$ and average minimum temperature is $5.6^{\circ} \mathrm{C}$ and the mean annual precipitation is $3,068 \mathrm{~mm}$ to $3,353.3 \mathrm{~mm}$. The forest has been managed as community forest. The forest is natural uneven and mixed in composition of $S$. wallichii (Chilaune), C. indica (Dhale Katus), Alnus nepalensis (Utis), Quercus semecarpifolia (Khasru), Rhododendron spp. (Laliguras), Bombax ceiba (Simal) and others.

\section{Data collection}

The existed variation in the population was detected from operational plan of the community forest. We selected 39 juveniles of $C$. indica purposively from the whole study area to represent existed variation of site, mode of origin, density, age and size (Adinugroho and Sidiyasa, 2006; Dorado et al., 2006; Edwards Jr et al., 2006). Vernier Calliper (precision $1 \mathrm{~mm}$ ) was used to measure diameter of each individual juvenile at $10 \mathrm{~cm}$ above the ground level by following the rules of Chaturvedi and Khanna (2011). Similarly, the linear tape (precision $1 \mathrm{~cm}$ ) was used to measure the total length from base to tip of the plant after destructive felling. The stem, leaves and branches were isolated and weighed (precision $0.1 \mathrm{~g}$ ) after felling. Samples for oven dry weight was collected from stem, leaves and branches and dried at $105^{\circ} \mathrm{C}$ at the laboratory of Institute of Forestry, Pokhara. The volume of stem was estimated using the principle of water displacement. The descriptive statistics of the data used for modeling is given in table 1 .

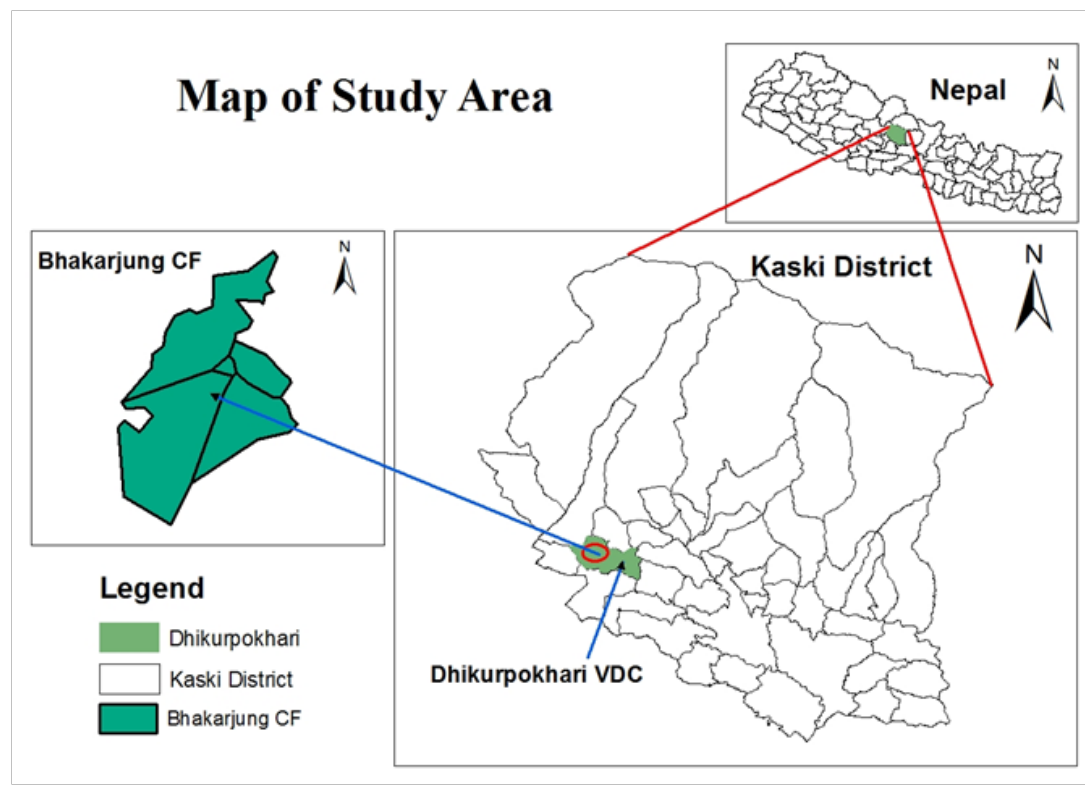

Fig.1: Location of study site 
Table 1: Descriptive statistics of the data used for modelling

\begin{tabular}{|c|c|c|}
\hline $\begin{array}{c}\text { Diameter } \\
\text { class }\end{array}$ & Variables & $\begin{array}{c}\text { Mean } \pm \text { std. error } \\
\text { (range) }\end{array}$ \\
\hline \multirow[t]{5}{*}{$0-1$} & Diameter $(\mathrm{cm})$ & $\begin{array}{r}0.873 \pm 0.022 \\
(0.82-0.96)\end{array}$ \\
\hline & Height (m) & $1.26 \pm 0.073(0.91-1.4)$ \\
\hline & Wood density $\left(\mathrm{gcm}^{-3}\right)$ & $0.46 \pm 0.045(0.36-0.60)$ \\
\hline & Biomass (g) & $\begin{array}{r}48.12 \pm 4.834 \\
(34.00-61.43)\end{array}$ \\
\hline & Number & 6 \\
\hline \multirow[t]{5}{*}{$1-2$} & Diameter $(\mathrm{cm})$ & $1.50 \pm 0.051(1.03-1.92)$ \\
\hline & Height (m) & $2.07 \pm 0.096(1.22-3.01)$ \\
\hline & Wood density $\left(\mathrm{gcm}^{-3}\right)$ & $0.48 \pm 0.007(0.42-0.54)$ \\
\hline & Biomass (g) & $\begin{array}{l}211.28 \pm 19.948 \\
(54.71-477.91)\end{array}$ \\
\hline & Number & 26 \\
\hline \multirow[t]{5}{*}{$2-3$} & Diameter $(\mathrm{cm})$ & $2.33 \pm 0.090(2.09-2.73)$ \\
\hline & Height (m) & $2.47 \pm 0.113(2.04-2.90)$ \\
\hline & Wood density $\left(\mathrm{gcm}^{-3}\right)$ & $0.46 \pm 0.017(0.39-0.53)$ \\
\hline & Biomass (g) & $\begin{array}{c}570.78 \pm 46.996 \\
(481.85-816.63)\end{array}$ \\
\hline & Number & 7 \\
\hline \multirow[t]{5}{*}{ Overall } & Diameter $(\mathrm{cm})$ & $1.55 \pm 0.078(0.82-2.73)$ \\
\hline & Height (m) & $2.02 . \pm 0.088(0.91-3.01)$ \\
\hline & Wood density $\left(\mathrm{gcm}^{-3}\right)$ & $0.48 \pm 0.008(0.36-0.60)$ \\
\hline & Biomass (g) & $\begin{array}{r}249.72 \pm 30.187 \\
(34-816.63)\end{array}$ \\
\hline & Number & 39 \\
\hline
\end{tabular}

Table 2: Candidate models considered

\section{Data Analysis}

Dimensional analysis, the most common method, is used to predict individual tree biomass (Whittaker and Woodwell, 1968). This method basically depends on the consistency of an allometric relationship between plant dimensions (usually dbh and/ or height) and biomass for a given species, group of species, or growth form. The juvenile biomass of $C$. indica was modeled by using diameter alone $\left(\mathrm{D}, \mathrm{D}^{2}\right)$, diameter and height combined $\left(\mathrm{DH}, \mathrm{D}^{2} \mathrm{H}\right)$, diameter and wood density combined $\left(\rho \mathrm{D}, \rho \mathrm{D}^{2}\right)$ and diameter, height and wood density combined $\left(\rho \mathrm{DH}, \rho \mathrm{D}^{2} \mathrm{H}\right)$. Juvenile biomass models were designated by applying each of the eight independent variables and termed first model category for a model with $\mathrm{D}$ alone, second model category for a model with $\mathrm{D}^{2}$ and third model category for a model with $\mathrm{DH}$ and so on resulting in eight different model categories in total and these eight model categories consist 13 models of different forms (i.e. $8 \times 13=104$ alternative models, see Table 2 for details).

The least square regression technique was used to develop biomass models. The models were estimated using "library (minpack.lm)" package in which $\operatorname{lm}$ (for linear models), nls and

\begin{tabular}{lll}
\hline Specification & Model form & References \\
\hline M1 & $\mathrm{W}_{\mathrm{i}}=\beta_{0} \mathrm{X}_{\mathrm{i}}^{\beta 1}+\varepsilon \mathrm{i}$ & Huxley and Teissier (1936) \\
M2 & $\mathrm{W}_{\mathrm{i}}=\beta_{0} \exp \left(\beta_{1} \mathrm{X}_{\mathrm{i}}\right)+\varepsilon \mathrm{i}$ & Rizvi et al. $(2008)$ \\
M3 & $\mathrm{W}_{\mathrm{i}}=\beta_{0} \exp \left(-\beta_{1} / \mathrm{X}_{\mathrm{i}}\right)+\varepsilon \mathrm{i}$ & Schumacher (1939) \\
M4 & $\mathrm{W}_{\mathrm{i}}=\beta_{0}\left[1-\exp \left(-\beta_{1} \mathrm{X}_{\mathrm{i}}\right)\right] 3+\varepsilon \mathrm{i}$ & Bertalanffy (1949) \\
M5 & $\mathrm{W}_{\mathrm{i}}=\beta_{0} \exp \left(\beta_{1} / \mathrm{X}_{\mathrm{i}}\right)+\varepsilon \mathrm{i}$ & Modified after Schumacher (1939) \\
M6 & $\mathrm{W}_{\mathrm{i}}=\beta_{0}+\beta_{1} \mathrm{X}_{\mathrm{i}}+\beta_{2} \mathrm{X}_{\mathrm{i}}^{2}+\varepsilon \mathrm{\varepsilon}$ & Brown (1997) \\
M7 & $\mathrm{W}_{\mathrm{i}}=\beta_{0}+\beta_{1} \mathrm{X}_{\mathrm{i}}^{2}+\varepsilon \mathrm{i}$ & Sharma (2011) \\
M8 & $\mathrm{W}_{\mathrm{i}}=\beta_{0}+\beta_{1} / \mathrm{X}_{\mathrm{i}}+\beta_{2} \mathrm{X}_{\mathrm{i}}^{2} \varepsilon \mathrm{i}$ & Sharma (2011) \\
M9 & $\mathrm{W}_{\mathrm{i}}=\beta_{0}+\beta_{1} \mathrm{X}_{\mathrm{i}}+\varepsilon \mathrm{i}$ & Spurr (1952) \\
M10 & $\mathrm{W}_{\mathrm{i}}=\beta_{0}+\mathrm{X}_{\mathrm{i}}^{\beta 1}+\varepsilon \mathrm{i}$ & Subedi and Sharma (2012) \\
M11 & $\mathrm{W}_{\mathrm{i}}=\mathrm{X}_{\mathrm{i}} /\left(\beta_{0}+\beta_{1} \mathrm{X}_{\mathrm{i}}\right)+\varepsilon \mathrm{i}$ & Hosoda and Iehara (2010) \\
M12 & $\mathrm{W}_{\mathrm{i}}=\mathrm{X}_{\mathrm{i}}^{2} /\left(\beta_{0}+\beta_{1} \mathrm{X}_{\mathrm{i}}\right)+\varepsilon \mathrm{i}$ & Modified after Hosoda and Iehara (2010) \\
M13 & $\mathrm{W}_{\mathrm{i}}=\mathrm{X}_{\mathrm{i}}^{2} /\left(\beta_{0}+\beta_{1} \mathrm{X}_{\mathrm{i}}^{2}\right)+\varepsilon i$ & Modified after Hosoda and Iehara (2010)
\end{tabular}

Note: $\mathrm{W} i=$ biomass of individual $i(\mathrm{~g}), x i=$ independent variable for juvenile $i$ [eight independent variable alternatives such as (1) $D$; (2) $D^{2}$; (3) $D H$; (4) $D^{2} H$; (5) $\rho D$; (6) $\rho D^{2}$; (7) $\rho D H$; and (8) $\left.\rho D^{2} H\right]$, $D i=$ diameter $(\mathrm{cm}) ; H i=$ height $(\mathrm{m}) ; \rho=$ wood density $\left(\mathrm{gcm}^{-3}\right)$, and $b_{1}, b_{2}, b_{3}=$ parameters to be estimated, and $\varepsilon i=$ unexplained error. 
nlsLM (for non linear models) commands in $\mathrm{R}$ (R Core Team, 2012). The models were evaluated by applying various criteria such as significance of parameter estimates, residual standard error (RSE), adjusted coefficient of determination ( $\mathrm{R}^{2}$ adj), Akaike Information Criterion (AIC), Average deviation and Graphs of residuals, scaled and quantile-quantile (Q-Q).

\section{Comparing the equations to previously published equations}

We used model of Chapagain et al. (2014) to the current data to compare with the best selected model. The allometric equation developed by Chapagain et al. (2014) for juvenile of Shorea robusta, Acacia catechu and Terminalia tomentosa is:

$$
\begin{aligned}
\mathrm{W} i= & 49.415+(\text { dia*height })^{\wedge}(1.239-0.033 / \\
& (\text { dia*height })) \text { for } S . \text { robusta } \\
\mathrm{W} i= & 47.904+(\text { dia*height })^{\wedge}(1.239-0.033 / \\
& (\text { dia*height })) \text { for } A . \text { catechu } \\
\mathrm{W} i= & 50.926+(\text { dia*height })^{\wedge}(1.239-0.033 / \\
& (\text { dia*height })) \text { for } T . \text { tomentosa }
\end{aligned}
$$

Where $W i$ is total above ground biomass in gram/ juvenile, dia is the diameter $(\mathrm{cm})$ measured 10 $\mathrm{cm}$ above the ground level and height is the total length $(\mathrm{m})$ of plant from ground level to top of the juvenile. The equation of Chapagain et al. (2014) was constructed from the data collected from 40 juvenile individual for each species of $S$. robusta, A. catechu and T. tomentosa. The diameters used to establish this equation ranged from 0.22 to $3.17 \mathrm{~cm}$ (S. robusta), 0.17 to $3.15 \mathrm{~cm}$ (A. catechu) and 0.23 to $3.17 \mathrm{~cm}$ (T. tomentosa).

\section{Results and discussion}

\section{Developing allometric equation}

Parameter estimates of 83 models out of 104 models $(8 * 13=104$ models or 13 models in each model category, Table 2) were found to be significant at $95 \%$ confidence interval. This shows that $79.8 \%$ of the models ( 83 significant models) tested in this study are more likely to be genuine and unlikely to have occurred by random chance to the data. $\mathrm{RSE}=42 \mathrm{~g}$ i.e. unexplained error by the models was still left unexplained inspite of well fitting of the models to the modelling data. Table 3 shows the fit statistics and parameter estimates of the best models from each model category.

M1 from fourth model category, M7 from first model category and M9 from second model category showed the best fits (smallest RSE, AIC, average deviation and largest $\mathrm{R}^{2} \mathrm{adj}$ ) among the models. The model M1, appeared in the fourth, third, first, first, second, first, first and first rank within the models from the first, second, third, fourth, fifth, sixth, seventh and eighth model category, respectively, which is the most widely used model to develop biomass model (TerMikaelian and Korzukhin, 1997; Sharma, 2011; Miksys et al., 2007). From the evaluation of fit statistics, M1 seems to be the most accurate and precise among the fourth model category and followed by the model M7 of the first model category, M9 of the second model category, M1 from the eighth model category, M1 from the third

\begin{tabular}{|c|c|c|c|c|c|c|c|c|}
\hline \multirow{2}{*}{$\begin{array}{c}\text { Model } \\
\text { category }\end{array}$} & \multirow[b]{2}{*}{ Model } & \multirow[b]{2}{*}{$\begin{array}{c}\text { Explanatory } \\
\text { variable** }\end{array}$} & \multicolumn{2}{|c|}{ Parameter estimates } & \multicolumn{4}{|c|}{ Fit Statistics } \\
\hline & & & $\beta_{0}$ & $\beta_{1}$ & $\mathbf{R}^{2}$ adj. & RMSE & AIC & $\begin{array}{c}\text { Average } \\
\text { Deviation (\%) }\end{array}$ \\
\hline 1 & M7 & $\mathrm{D}$ & -35.73 & 109.7 & 0.9338 & 49.15 & 418.43 & 19.02 \\
\hline 2 & M9 & $\mathrm{D}^{2}$ & -35.73 & 109.7 & 0.9338 & 49.15 & 418.43 & 19.02 \\
\hline 3 & M1 & DH & 40.20 & 1.45 & 0.9198 & 50.08 & 425.89 & 15.09 \\
\hline 4 & M1 & $\mathrm{D} 2 \mathrm{H}$ & 52.28 & 0.89 & 0.9508 & 42.34 & 406.8 & 13.26 \\
\hline 5 & M14 & $\rho D$ & 3137.95 & 1.94 & 0.8169 & 81.73 & 458.09 & 24.00 \\
\hline 6 & M1 & $\rho \mathrm{D}^{2}$ & 186.05 & 1.18 & 0.9033 & 59.38 & 433.17 & 19.53 \\
\hline 7 & M1 & $\rho \mathrm{DH}$ & 111.11 & 1.51 & 0.8407 & 76.25 & 452.67 & 20.57 \\
\hline 8 & M1 & $\rho \mathrm{D}-\mathrm{H}$ & 91.11 & 0.97 & 0.9310 & 50.15 & 420 & 14.67 \\
\hline
\end{tabular}
model category, M1 from sixth model category, M1 from seventh model category and M3 from fifth model category. Graphs of model residuals, scaled and normal Q-Q were also examined.

Table 3: The value of coefficient and fit statistics of the best model of each model category 
The unstandardized residuals against the fitted values with a smooth superimposed curve formodel M1 from model category fourth, model M7 from model category first and model M9 from model category second is shown in figure 2. Here we are looking for evidence of curvature and outliers. The graph of M1 from category fourth shows negligible curvature and outliers in comparison to remaining two models. Absence of curvature in M1 category fourth suggests us the absence of local bias in the model. The figure 3 shows the square root of the standardized residuals against fitted value along with smooth line. Departure from horizontal lines signify heteroskedasticity contradicting the model assumption " $\varepsilon$ i have constant variance", (Robinson and Hamann, 2011) but the model M1 from category fourth shows the less heteroskedasticity than other models. Similarly, figure 4 shows a Q-Q plot of the standardized residuals against the normal distribution. Here the ideal plot is a straight line, although modest departures from straightness are often acceptable (due to large-sample theory). Departures from a straight line in this plot may indicate non-normality of the residuals or non-constant variance, or both (Robinson and Hamann, 2011). But in our analysis, we found all the points are in a reasonably straight line which indicates the normal distribution of residuals.

The independent variable $\mathrm{D}^{2} \mathrm{H}$ (combination of diameter and total height) demonstrated strong capacity to predict juvenile biomass in case of model M1 from model category fourth in comparison to others. Therefore, the following model M1 was selected for the estimation of juvenile biomass of $C$. indica from the first stage of model development. Here after this selected model is referred as M14 for further analysis and comparision with previously published models.

$\hat{W} i=52.28\left(D_{i}^{2} H_{i}\right)^{0.89}$ M14

\section{Comparison of M14 with previously published equations}

Table 4: The average deviation and AIC values of various models

\begin{tabular}{lrr}
\hline \multicolumn{1}{c}{ Model } & \multicolumn{1}{c}{$\begin{array}{c}\text { Average } \\
\text { Deviation (\%) }\end{array}$} & \multicolumn{1}{c}{ AIC } \\
\hline M14 & 13.26 & 406.8 \\
$\begin{array}{l}\text { Chapagain et al. (2014) } \\
\text { S. robusta }\end{array}$ & 64.85 & 428 \\
$\begin{array}{l}\text { Chapagain et al. (2014) } \\
\text { A. catechu }\end{array}$ & 65.41 & 428 \\
$\begin{array}{l}\text { Chapagain et al. (2014) } \\
\text { T. tomentosa }\end{array}$ & 64.29 & 428 \\
\hline
\end{tabular}

The average deviation for individual trees of the model M14 is smaller than that of previously published models (Table 4). Similarly, the AIC value for the model M14 is also smaller than that of previously published models (Table 4). The AIC values of the model of Chapagain et al. (2014) for all three species is same because of the same
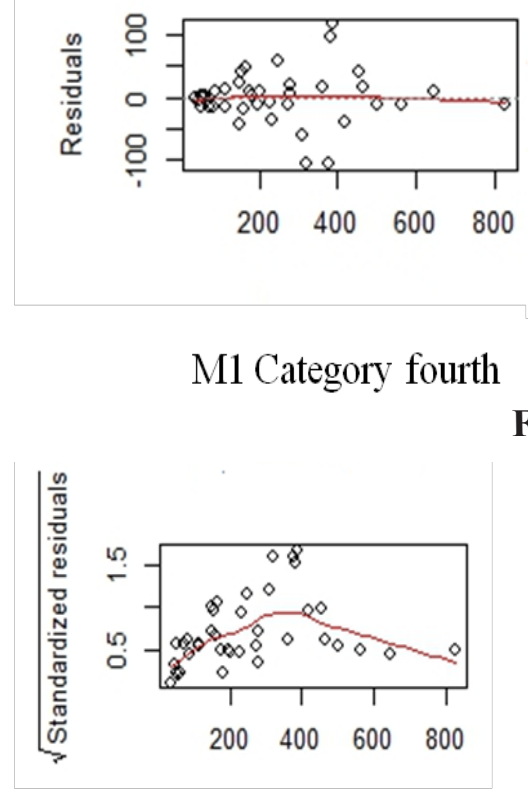

M1 Category fourth

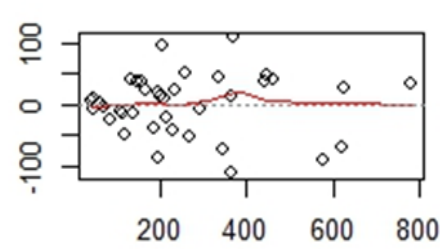

Fitted values

M7 Category first

Fig. 2: Residual vs Fitted value

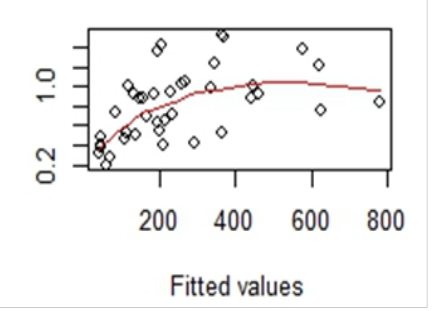

M7 Category first

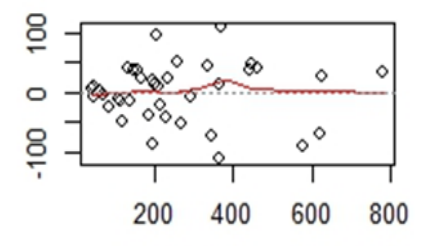

M9 Category second

(1)

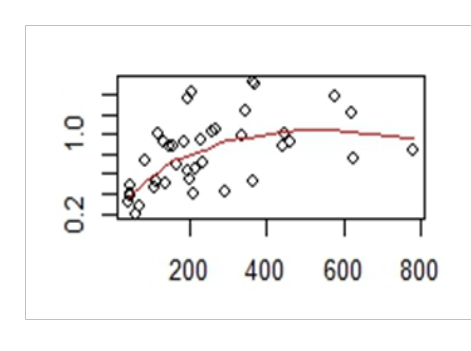

M9 Category second

Fig. 3: Scale location 


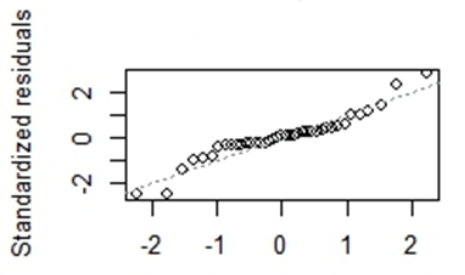

M1 Category fourth

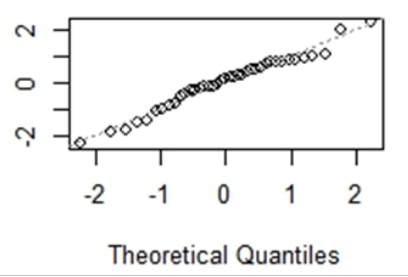

M7 Category first

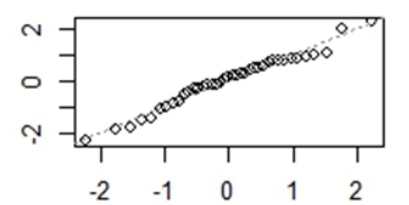

M9 Category second

Fig. 4: Normal Quantile-Quantile plot

form of the model except for the difference in the values of intercept and coefficients. When the equations of Chapagain et al. (2014) for all three species were applied to our data, the predicted values were underestimated. This proof can be seen from confidence interval $(\mathrm{CI})$ values given in table 5. At 95\% CI, upper and lower limit of the mean biomass from the model of Chapagain et al. (2014) for all three species were smaller than the observed values. While analyzing the lower and upper limit of CI, the model M14 is closer to the mean value of the observed biomass (Table 5). A possible justification for lower prediction when applying the model of Chapagain et al. (2014) to the data from this study is the differences in the species and their form. Though data for both of the studies were collected from Nepal, the variation in site and tree form might have some role in variation in total biomass.

Apart from this, the analysis of paired sampled t-test from table 6 shows that for two tailed at $95 \%$ confidence interval, the mean of the observed data and the proposed model is statistically significantly different from the predicted mean using the model of Chapagain et al. (2014) for all the three species. But there is no statistical significant difference between the observed data and the model M14. On the other hand the model M14 has statistical significant difference with the model of Chapagain et al. (2014) for all three species.

Table 6: Paired t-test at $95 \%$ confidence interval of the mean biomass

\begin{tabular}{|c|c|c|}
\hline Pairs & t-statistic & $\begin{array}{l}\text { Significance } \\
\text { (Two tailed) }\end{array}$ \\
\hline $\begin{array}{l}\text { Observed - Chapagain et al. } \\
2014 \text { (S. robusta) }\end{array}$ & 6.672 & 0.00 \\
\hline $\begin{array}{l}\text { Observed - Chapagain et al. } \\
2014 \text { (A. catechu) }\end{array}$ & 6.723 & 0.00 \\
\hline $\begin{array}{l}\text { Observed - Chapagain et al. } \\
2014 \text { (T. tomentosa) }\end{array}$ & 6.621 & 0.00 \\
\hline $\begin{array}{l}\text { M14 - Chapagain et al. } 2014 \\
(\text { S. robusta })\end{array}$ & 6.923 & 0.00 \\
\hline $\begin{array}{l}\text { M14 - Chapagain et al. } 2014 \\
(\text { A. catechu) }\end{array}$ & 6.977 & 0.00 \\
\hline $\begin{array}{l}\text { M14 - Chapagain et al. } 2014 \\
(\text { T. tomentosa) }\end{array}$ & 6.869 & 0.00 \\
\hline Observed - M14 & 0.592 & 0.558 \\
\hline
\end{tabular}

From the analysis of application of proposed models and previously developed models, it would be better to consider site specific model for precise estimation of forest biomass. Similar findings were reported by Basuki et al. (2009), Cairns et al. (2003) and Nelson et al. (1999) when they applied previously published models to their data. In contrast to these results, Chave et al.

Table 5: The confidence interval (CI) of the mean from various models

\begin{tabular}{|c|c|c|c|c|c|}
\hline Parameters & Observed & M14 & $\begin{array}{c}\text { Chapagain et } \\
\text { al. (2014) } \\
\text { S. robusta } \\
\end{array}$ & $\begin{array}{c}\text { Chapagain et al. } \\
\text { (2014) } \\
\text { A. catechu }\end{array}$ & $\begin{array}{c}\text { Chapagain et al. } \\
\text { (2014) } \\
\text { T. tomentosa }\end{array}$ \\
\hline Mean biomass (g) & 252.47 & 248.48 & 53.99 & 52.48 & 55.50 \\
\hline $\begin{array}{l}95 \% \text { CI Lower limit } \\
\text { of mean biomass }(\mathrm{g})\end{array}$ & 193.24 & 192.47 & 53.08 & 51.57 & 54.59 \\
\hline $\begin{array}{l}95 \% \text { CI Upper limit } \\
\text { of mean biomass (g) }\end{array}$ & 311.70 & 304.49 & 54.89 & 53.38 & 56.40 \\
\hline $\begin{array}{l}\text { The number of } \\
\text { Juvenile plants }\end{array}$ & 39 & 39 & 39 & 39 & 39 \\
\hline
\end{tabular}


(2005) stated that local species specific models are not needed; instead, generalized allometric relationships can be employed. The effective way might be the grouping of species by broad forest types or ecological zones than developing models for specific species because the local species specific equations do not improve the accuracy significantly. The prediction using Chapagain et al. (2014) showed that the upper limit of prediction is much lower than the observed values (Table 5) at 95\% confidence interval. The upper boundaries of the observed data, prediction using model M14 and prediction using Chapagain et al. (2014) are 816.63, 805.82, and 62.28 (S. robusta), 60.77 (A. catechu) and 63.79 (T. tomentosa) respectively. The table 5 paired sampled t-test supports the CI mentioned above. The mean of the observed and M14 are significantly higher that the mean of the models of Chapagain et al. (2014) for all three species. Therefore, from the analysis of fit statistics while developing the models and comparision of developed model with previously published models, the M14 is selected for the estimation of above ground biomass of juvenile stage plants of $C$. indica.

\section{Conclusion}

The most suitable allometric equation to estimate the above ground biomass of juvenile plants of $C$. indica is M14 i.e. $\hat{\mathrm{W}} \mathrm{i}=52.28\left(\mathrm{D}_{\mathrm{i}}^{2} \mathrm{H}_{\mathrm{i}}\right)^{0.89}$. This model explained $>95 \%$ juvenile biomass of $C$. indica with $\mathrm{RSE}=42.34 \mathrm{~g}, \mathrm{AIC}=406.8$ and average deviation $=13.26$. On the other hand, the selected model M14 is comparatively closer to the observed values than the other models.

\section{Acknowledgements}

We are thankful to anonymous reviewers for their comments and suggestions to earlier version of manuscript. This study was financially supported by Ecosystem Based Adaptation (EBA) program in Mountain Ecosystem in Nepal.

\section{References}

Adinugroho, W. C. D. and Sidiyasa, K. 2006. Biomass estimation model of above-ground mahogany (Swietenia macrophylla) tree. J Penel Hut Konser Alam 3 (1): 103-117.

Basuki, T. M., van Laake, P. E., Skidmore, A. K. and Hussin, Y. A. 2009. Allometric equations for estimating the above-ground biomass in tropical lowland Dipterocarp forests. Forest Ecology and Management 257 (8): 1684-1694.

Bertalanffy, L. V. 1949. Problems of organic growth. Nature 163 (4135): 156-158.

Brown, S. 1997. Estimating Biomass and Biomass Change of Tropical Forests: A Primer. FAO Forestry paper 134. FAO, Rome, Italy.

Cairns, M. A., Olmsted, I., Granados, J. and Argaez, J. 2003. Composition and aboveground tree biomass of a dry semievergreen forest on Mexico's Yucatan Peninsula. Forest Ecology and Management 186: $125-132$.

Chapagain, T., Sharma, R. P. and Bhandari, S. K. 2014. Modelling above-ground biomass for three tropical tree species at their juvenile stage. Forest Science and Technology 10 (2): 51-60.

Chaturvedi, A. N. and Khanna, L. S. 2011. Forest Mensuration and Biometry. 5th Edition. Khanna Bandhu, Dheradun, India.

Chaturvedi, R. K. and Raghubanshi, A. S. 2013. Above-ground biomass estimation of small diameter woody species of tropical dry forest. New Forests 44 (4): 509-519.

Chaturvedi, R. K., Raghubanshi, A. S. and Singh, J. S. 2012. Biomass estimation of dry tropical woody species at juvenile stage. The Scientific World Journal 1-5 (doi:10.1100/2012/790219).

Chave, J., Andalo, C., Brown, S., Cairns, M. A., Chambers, J. Q., Eamus, D., Folster, H., Fromard, F., Higuchi, N., Kira, T., Lescure, J. P., Nelson, B. W., Ogawa, H., Puig, H., Rie'ra, B. and Yamakura, T. 2005. Tree allometry and improved estimation of carbon stocks and balance in tropical forests. Oecologia 145 (1): 187-199.

Dorado, F. C., Dieguez-Aranda, U., Anta, M. B., Rodriguez, M. S. and von Gadow, K. 2006. A generalized height-diameter model including random components for radiata pine plantations in northwestern Spain. Forest Ecology and Management 229 (1-3): 202-213.

Edwards, Jr T. C., Cutler, D. R., Zimmermann, N. E., Geiser, L. and Moisen, G. G. 2006. 
Effects of sample survey design on the accuracy of classification tree models in species distribution models. Ecology Modell 199 (2): 132-141.

Francis, J. K. 2000. Estimating biomass and carbon content of saplings in Puerto Rican secondary forests. Caribbean Journal of Science 36 (3-4): 346-350.

Geudens, G., Staelens, J., Kint, V., Goris, R. and Lust, N. 2004. Allometric biomass equations for Scots pine (Pinus sylvestris L.) seedlings during the first years of establishment in dense natural regeneration. Annals of Forest Science 61 (7): 653-659.

Hosoda, K. and Iehara, T. 2010. Abovegroud biomass equations for individual trees of Cryptomeria japonica, Chamaecy parisobtusa and Larix kaempferi in Japan. Journal of Forest Research 15: 299-306.

Huxley, J. S. and Teissier, G. 1936. Terminology of relative growth. Nature 137 (3471): 780 781.

Jackson, J. K. 1994. Manual of Afforestation in Nepal. Forest research and survey center. Second edition, Kathmandu, Nepal.

Keith, H., Barrett, D. and Keena, R. 2000. Review of Allometric Relationships for Estimating Woody Biomass for New South Wales, the Australian Capital Territory, Victoria, Tasmania, and South Australia. National Carbon Accounting System Technical Report 5B. Australian Greenhouse Office, Canberra.

Ketterings, Q. M., Coe, R., van Noordwijk, M., Ambagau, Y. and Palm, C. A. 2001. Reducing uncertainty in the use of allometric biomass equations for predicting above-ground tree biomass in mixed secondary forests. Forest Ecology and Management 146 (1-3): 199209.

Miksys, V., Varnagiryte-Kabasinskiene, I., Stupak, I., Kestutis, A., Kukkola, M. and Wo' jcik, J. 2007. Above-ground biomass functions for Scots pine in Lithuania. Biomass Bioenergy 31 (10): 685-692.

Muukkonen, P. 2007. Generalized allometric volume and biomass equations for some tree species in Europe. Euro Journal of Forest Research 126 (2): 157-166.

Nelson, B. W., Mesquita, R., Pereira, J. L. G., de
Souza, S. G. A., Batista, G. T. and Couto, L. B. 1999. Allometric regressions for improved estimate of secondary forest biomass in the central Amazon. Forest Ecology and Management 117 (1-3): 149-167.

Niklas, K. J. 1994. Plant Allometry: The Scaling of Form and Process. The University of Chicago Press, Chicago, USA.

R Core Team. 2012. R: A Language and Environment for Statistical Computing. R Foundation for Statistical Computing, Vienna, Austria. ISBN 3-900051-07-0, URL http://www.R-project.org/.

Rizvi, R. H., Gupta, V. K. and Pandit, A. 2008. Comparison of various linear and non-linear functions for estimating biomass and volume of Dalbergia sissoo grown under rainfed conditions. Indian Journal of Agricultural Science 78 (2): 138-141.

Robinson, A. P. and Hamann, J. D. 2011. Forest Analytics with R, an Introduction. New York: Springer, USA.

Schumacher, F. X. 1939. A new growth curve and its application to timber-yield studies. Journal of Forest 37: 819-820.

Segura, M. and Kanninen, M. 2005. Allometric models for tree volume and total aboveground biomass in a tropical humid forest in Costa Rica. Biotropica 37 (1): 2-8.

Sharma, R. P. 2011. Allometric models for totaltree and component tree biomass of Alnus nepalensis D. Don in Nepal. Indian Forester 137 (12): 1386-1390.

Shrestha, D. B. 2013. Modelling Above-ground Biomass and Allometric Relationship of Castanopsis indica Growth in Mid hill Region of Nepal: an Analytical Study from Kaski District of Nepal. M.Sc. Thesis, Institute of Forestry, Tribhuvan University, Nepal.

Spurr, S. H. 1952. Forest Inventory. Ronald press, New York, USA.

Subedi, M. and Sharma, R. P. 2012. Allometric biomass models for bark of Cinnamo mumtamala in mid-hill of Nepal. Biomass and Energy 47: 44-49.

Tamrakar, P. R. 2000. Biomass and Volume Tables with Species Description for 
Community Forest Managment. MoFSC, NARMSAP-TISC, Kathmandu, Nepal.

Ter-Mikaelian, M. T. and Korzukhin, M. D. 1997. Biomass equations for sixty five north American tree species. Forest Ecology and Management 97 (1): 1-24.

Wagner, R. G. and Ter-Mikaelian, M. T. 1999. Comparison of biomass component equations for four species of northern coniferous tree seedlings. Annals of Forest Science 56 (3): 193-199.
Whitataker, R. H. and Woodwell, G. M. 1968. Dimension and production relations of trees and shrubs in the Brookhaven forest, New York. Journal of Ecology 56: 1-25.

Zianis, D., Muukkonen, P., Makipa, R. and Mencuccini, M. 2005. Biomass and Stem Volume Equations for Tree Species in Europe. Silva Fenn. Monogr. 